Article

\title{
Asymmetrical Competition between Aedes aegypti and Culex quinquefasciatus (Diptera: Culicidae) Coexisting in Breeding Sites
}

\author{
Juan C. Santana-Martínez ${ }^{1}$, Jorge Molina ${ }^{2}$ and Jenny Dussán ${ }^{1 \text {,* (D) }}$ \\ 1 Centro de Investigaciones Microbiológicas (CIMIC), Departamento de Ciencias Biológicas, \\ Universidad de los Andes, Carrera 1 No. 18A-10, Bogotá J-206, Colombia; jc.santana2010@uniandes.edu.co \\ 2 Centro de Investigaciones en Microbiología y Parasitología Tropical (CIMPAT), \\ Departamento de Ciencias Biológicas, Universidad de los Andes, Carrera 1 No. 18A-10, Bogotá A-103, \\ Colombia; jmolina@uniandes.edu.co \\ * Correspondence: jdussan@uniandes.edu.co; Tel.: +57-1-3394949 (ext. 3644)
}

Academic Editor: Walter J. Tabachnick

Received: 6 September 2017; Accepted: 11 October 2017; Published: 24 October 2017

\begin{abstract}
Aedes aegypti and Culex quinquefasciatus are mosquito vectors for several tropical diseases that represent a current public health problem. The ecological requirements for each species are different, however, both species show high biological adaptability, which promotes their coexistence in the same breeding sites. The purpose of this study was to assess the effect of larval association between $A$ e. aegypti and $C x$. quinquefasciatus under different laboratory conditions of food supply and temperature, and under field simulated conditions like peridomestic containers. Our findings showed that under field simulated conditions there was no asymmetrical competition in mixed cultures with the different $C x$. quinquefasciatus/Ae. aegypti ratios tested. However, under laboratory conditions in which different doses of food supply were evaluated, it was observed that competition between the two species takes place. Larval coexistence under food scarcity conditions ( $0.95 \mathrm{mg} / \mathrm{larva}$ ) showed that $A$ e. aegypti had a greater adult emergence than $C x$. quinquefasciatus and was capable of depriving $C x$. quinquefasciatus of the food needed to complete metamorphosis. In an intermediate dose of food ( $1.9 \mathrm{mg} /$ larva), the dry weight of $C x$. quinquefasciatus adults decreased, and their larval development time increased when $C x$. quinquefasciatus/Ae. aegypti ratio was low. Also, a temperature effect was assessed demonstrating that $C x$. quinquefasciatus was more vulnerable to changes in temperature. We suggest that $A$ e. aegypti is more successful in exploiting microhabitats when food is scarce, due to its scrape active feeding habitats and fast larval development times. Therefore, in conditions of food paucity both species will compete, and Ae. aegypti larvae will prevail.
\end{abstract}

Keywords: Aedes aegypti; Culex quinquefasciatus; interspecific competition; breeding places; vector ecology; larval association

\section{Introduction}

Aedes aegypti and Culex quinquefasciatus are mosquito vectors for several important tropical diseases that represent a current public health problem such as Zika fever, yellow fever, chikungunya, West-Nile fever, filariasis, and encephalitis [1,2]. Furthermore, many studies have shown high biological adaptability for both species. For instance, considering Ae. aegypti, a previous study [3] reported multiple breeding sites including rock holes, tree holes, leaf axils, ground pools, and tires, among others, demonstrating a wide use of habitats by this species. Also, according to a study based on single nucleotide polymorphisms (SNPs) and four sequenced nuclear genes, Ae. aegypti has at least twelve polymorphic populations distributed all over Africa, Asia, and the Americas, 
thus demonstrating that this species is adaptively flexible and maintains significant genetic variation [4]. In addition, Ae. aegypti has been reported as an opportunistic feeder, capable of rapidly responding to environmental changes and possessing egg dormancy [4].

Cx. quinquefasciatus has also been reported as an opportunistic feeder that takes blood from a wide range of mammals and birds [5], and it has an olfactory memory, a mechanism that indicates the most accurate oviposition site to a gravid female mosquito. In addition, it is capable of proliferating in urban areas where blocked drains, pools collected from run-off domestic sewage, and pit latrines provide ideal larval environments, therefore indicating that it is a species tolerant to extreme values of $\mathrm{pH}$, high organic material, and high salinity [6]. Furthermore, Cx. quinquefasciatus survives from egg to adults in temperatures ranging from $15^{\circ} \mathrm{C}$ to $34^{\circ} \mathrm{C}$ [7].

Both mosquito species, $C x$. quinquefasciatus and Ae. aegypti, share similar patterns during their life cycles because they have aquatic as well as terrestrial stages [8]. The larvae of both are found in a variety of anthropogenic habitats, including artificial containers, storm drains, drainage ditches, and septic tanks [8-14]. Also, both species tend to colonize mainly urban and suburban areas in tropical countries due to the suitable climate conditions for their postembryonic development, resulting in overlapping distributions in much of the tropics $[15,16]$. However, current evidence showed that in spite of sharing life history traits, mosquito larvae of $C x$. quinquefasciatus and Ae. aegypti differ in their feeding strategies and ecological requirements. Ae. aegypti have a shredding feeding mode and a predilection for temperatures above $25^{\circ} \mathrm{C}$, whereas $\mathrm{C} x$. quinquefasciatus have a collecting-filtering feeding mode and predilection for temperatures ranging $20-30{ }^{\circ} \mathrm{C}[7,17]$.

Ae. aegypti and $C x$. quinquefasciatus have significant roles as vectors of disease agents and the larvae of both species can be found coexisting in the same breeding containers [18,19], despite the differences in ecological requirements described above. The aim of this study was to evaluate the effects of interspecific competition between the preimaginal stages of Ae. aegypti and Cx. quinquefasciatus under different laboratory conditions of food supply and temperature, and under field simulated conditions. The results of this study could provide useful insights for designing control population strategies in breeding sites, as well as providing additional knowledge about the interaction between larvae of both species under different environmental variables that can affect the development and survival rates of the larvae.

\section{Materials and Methods}

\subsection{Larvae Collection}

Field-coexisting Ae. aegypti and Cx. quinquefasciatus larvae were collected from artificial containers filled with rainwater located in suburban areas of San Joaquin municipality in La Mesa, Cundinamarca, Colombia $\left(4^{\circ} 38^{\prime} 24.1^{\prime \prime} \mathrm{N}, 74^{\circ} 31^{\prime} 17.9^{\prime \prime} \mathrm{W}\right)$ during September 2016 . A total of 11 containers was sampled, from which 5 were plastic barrels, 2 were cement laundries, and 4 were plastic buckets. Both species of mosquito Ae. aegypti and Cx. quinquefasciatus were present in all the containers and no other mosquito species were found.

\subsection{Field Simulation Bioassays}

In order to assess the differences in preimaginal development and competition for food supply between Ae. aegypti and $C x$. quinquefasciatus in natural simulated conditions of development, the following bioassays were carried out at San Joaquin: Fifteen third-instar larvae of each species were placed in 320-mL plastic cups (72 $\times 87 \mathrm{~mm}$, width $\times$ depth) with a bottom net that allowed the water exchange (Figure 1). The following competition ratios Cx. quinquefasciatus/Ae. aegypti: 0:1; 1:1, and 1:0 were tested. Three $320-\mathrm{mL}$ plastic cups were placed in a larger plastic container $(34 \times 28.5 \times 11 \mathrm{~cm}$, length $\times$ width $\times$ depth) filled with nine liters of rain water obtained from the same sites where the larvae were collected. The large plastic container with the small plastic cups was protected from direct sunlight. 
The rate of adult production and wet body weight were registered in each experiment. To do that, the pupae obtained were separated before imaginal ecdysis, and the adults obtained were weighed (KERN 770 v2.3, KERN \& SOHN GmbH (c), Balingen, Germany). The air temperature was registered in the experiment site ten times per day with intervals of approximately $2 \mathrm{~h}$, and a mean of the daily data was obtained.

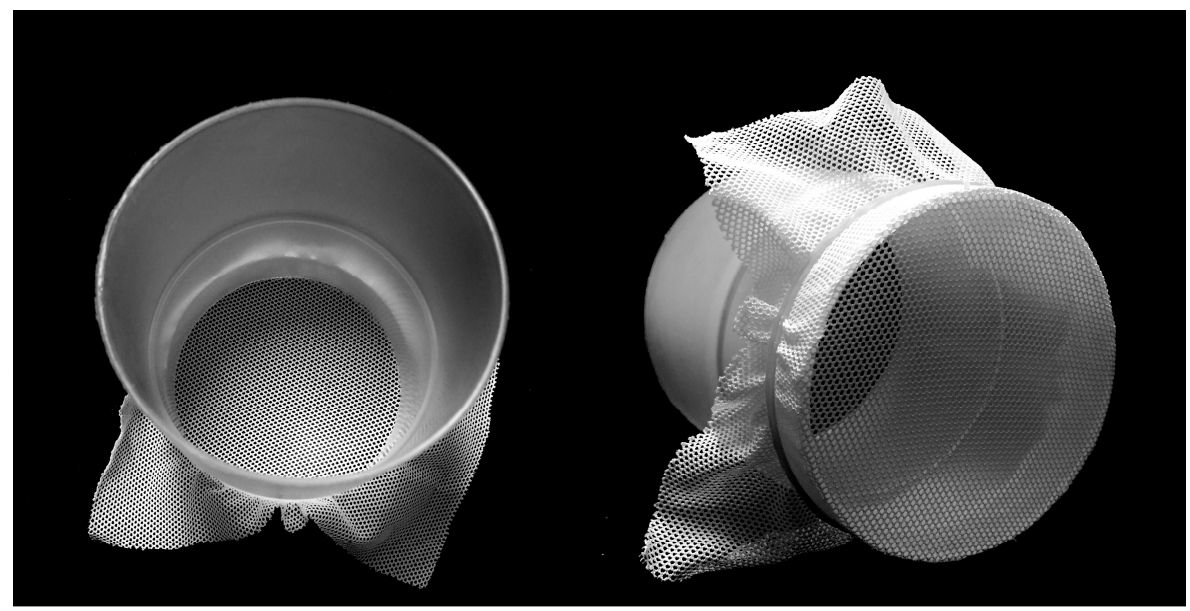

Figure 1. Plastic cups with a bottom net to evaluate preimaginal development and competition for food supply with different ratios between $C x$. quinquefasciatus/Ae. aegypti under natural simulated conditions.

\subsection{Laboratory Bioassays}

Laboratory bioassays were carried out following [20]. Briefly, Ae. aegypti and Cx. quinquefasciatus larvae collected were placed in a rearing cage at $30{ }^{\circ} \mathrm{C}, 75 \%$ of relative humidity $(\mathrm{RH})$, and light periods of 12:12 L:D. Then, adults were fed with lamb's blood and the eggs obtained from F1 were used in our laboratory experiments. Trials were carried out in a climate-controlled chamber set at $30{ }^{\circ} \mathrm{C}, 75 \% \mathrm{RH}$, and 12:12 L:D photoperiod.

The eggs obtained from both species were placed in separate containers with dechlorinated water. Pools of first-instar larvae were separated and placed in $250 \mathrm{~mL}$ glass containers (previously sterilized) (Cristar (C), Medellin, Colombia) containing $200 \mathrm{~mL}$ of dechlorinated water. Three food doses (Omega One Super Color Cichlid Pellets, (C) OmegaSea LLC, Painesville, OH, USA) ground to powder and previously sterilized, were tested: $2.83 ; 1.9$, and $0.95 \mathrm{mg} / \mathrm{larva}$.

Additionally, the influence of air temperature was studied by comparing larval competition at $22{ }^{\circ} \mathrm{C}$ and $30{ }^{\circ} \mathrm{C}$, using the intermediate food dose of $1.9 \mathrm{mg} /$ larva, which had been previously reported as being the most appropriate dosage for evincing competition [16].

The development time, dry body weight, and rate of adult production corresponding to each temperature and food dose were quantified to establish the effect of competition with the following ratios of $C x$. quinquefasciatus/Ae. aegypti larvae: 1:0;2:1; 1:1; 1:2, and 0:1. Fifteen larvae were used as one unit in all the ratios (e.g., 2:1 means 30 Cx. quinquefasciatus larvae and 15 Ae. aegypti larvae).

To avoid the formation of a film on the water surface that could prevent larvae respiration, during each of the first six days of larval development the food was supplied in doses proportional to age, i.e., $10 \%$ on the first and second day, $15 \%$ on the third, $21 \%$ on the fourth, and $22 \%$ on the fifth and sixth day. Pupae were separated before imaginal ecdysis, and the adults obtained were placed at a temperature of $-20^{\circ} \mathrm{C}$, dried at $80{ }^{\circ} \mathrm{C}$ for $24 \mathrm{~h}$, and finally weighed (KERN 770 v2.3, (c) KERN \& SOHN GmbH, Balingen, Germany).

\subsection{Statistical Analysis}

The software R v3.1.1 (C) The R Foundation, Vienna, Austria) was used for statistical analysis [21]. In all cases normality was tested with a Shapiro-Wilk test. A Student $t$-test was carried out to evaluate 
the effect of competition on the rate of adult production and the wet weight of the adults obtained under field simulated conditions [22].

The development time, dry weight, and the rate of adult production obtained under laboratory conditions were analyzed by Analysis of Variance (ANOVA) followed by a Tukey-Kramer test to separate averages among the different $C x$. quinquefasciatus/Ae. aegypti ratios tested. Among these data, few showed no normality, and they were analyzed by a Kruskal-Wallis test, followed by a Mann-Whitney $U$ test to establish significant differences between treatments.

Lineal regressions with different food doses were carried out to evaluate the effect of Cx. quinquefasciatus/Ae. aegypti ratios on the production of adult dry biomass [22]. The competition between both species was measured using the Relative Crowding Coefficient (RCC) described by [23] and modified by [24,25]:

$$
R C C s=\left\{\frac{\frac{1}{2} *\left(\frac{A e^{2: 1}}{C x^{2: 1}}\right)+\left(\frac{A e^{1: 1}}{C x^{1: 1}}\right)+2 *\left(\frac{A e^{1: 2}}{C x^{1: 2}}\right)}{3}\right\} /\left(\frac{A e^{1: 0}}{C x^{1: 0}}\right)
$$

When RCC $>1$, competition favors Ae. aegypti, and vice versa, if $\mathrm{RCC}<1, \mathrm{Cx}$. quinquefasciatus prevails.

\section{Results}

Data obtained in field simulation experiments showed no significant differences in the adult production rate of the two species between the three $C x$. quinquefasciatus/Ae. aegypti ratios evaluated (Table 1). In addition, wet adult weight showed also no significant differences between the ratios tested (Table 1). Together, these results indicated that under field simulated conditions, no asymmetrical competition could be observed between both species, and coexistence was possible in the same breeding sites. Asymmetrical competition occurs when one species has a large negative effect on a competitor, which in turn has a small effect on the first species [26].

Table 1. Effect of competition on the biological parameters evaluated under simulated field conditions.

\begin{tabular}{cccccc}
\hline \multirow{2}{*}{$\begin{array}{c}\text { Cx. quinquefasciatus/ } \\
\text { Ae. aegypti Ratio }\end{array}$} & $\mathbf{N}$ & $\begin{array}{c}\text { Adult Emergence } \\
\text { (Proportion } \pm \text { SD) }\end{array}$ & $\begin{array}{c}\text { Wet Adult Weight } \\
\text { (mg } \pm \text { SD) }\end{array}$ & $\begin{array}{c}\text { Adult Emergence } \\
\text { (Proportion } \pm \text { SD) }\end{array}$ & $\begin{array}{c}\text { Wet Adult Weight } \\
\text { (mg } \pm \text { SD) }\end{array}$ \\
\hline $1: 0$ & 6 & & & $0.90 \pm 0.06 \mathrm{a}$ & $0.94 \pm 0.03 \mathrm{a}$ \\
$1: 1$ & 6 & $0.92 \pm 0.08 \mathrm{a}$ & $0.91 \pm 0.03 \mathrm{a}$ & $0.92 \pm 0.08 \mathrm{a}$ & $0.94 \pm 0.05 \mathrm{a}$ \\
$0: 1$ & 6 & $0.94 \pm 0.08 \mathrm{a}$ & $0.90 \pm 0.05 \mathrm{a}$ & & \\
\hline
\end{tabular}

Means within a column block followed by the same letter are not significantly different according to Student $t$-test.

Under laboratory experiments at $30{ }^{\circ} \mathrm{C}$, development time in Ae. aegypti at a food dose of $2.83 \mathrm{mg} /$ larva showed no significant differences between the different $C x$. quinquefasciatus/Ae. aegypti ratios evaluated (Table 2). However, with a food dose of $0.95 \mathrm{mg} /$ larva and at ratios 2:1 and 1:1, we observed shorter times of development in Ae. aegypti, in contrast to those observed at ratios 0:1, $1: 2$, indicating a higher intraspecific vs. interspecific competition. Also, a reduction in the time of development in Ae. aegypti was observed with a food dose of $1.9 \mathrm{mg} /$ larva at ratios of 2:1 and 1:2 compared with ratios 1:1 and 0:1 (Table 2). Although the food was supplied in $\mathrm{mg} / \mathrm{larva}$, these ratios had a higher number of larvae, suggesting that Ae. aegypti larvae can exploit more efficiently the resources that were initially intended for both species. Moreover, at $1.9 \mathrm{mg} / \mathrm{larva}\left(22^{\circ} \mathrm{C}\right)$ we found significant differences between the ratios tested; however, the effect of competition and temperature on the development time at this dose remains unclear (Table 2), according to the ratios evaluated. 
Table 2. Effect of competition on the biological parameters evaluated under laboratory conditions.

\begin{tabular}{|c|c|c|c|c|c|c|c|}
\hline \multirow[b]{2}{*}{ Cx. quinquefasciatus/Ae. aegypti Ratio } & \multirow[b]{2}{*}{$\mathbf{N}$} & \multicolumn{3}{|c|}{ Ae. aegypti } & \multicolumn{3}{|c|}{ Cx.quinquefasciatus } \\
\hline & & $\begin{array}{l}\text { Time from Egg to Adult } \\
\quad \text { (Days } \pm \text { SD) }\end{array}$ & $\begin{array}{c}\text { Adult Emergence } \\
\text { (Proportion } \pm \text { SD) }\end{array}$ & $\begin{array}{l}\text { Dry Adult Weight } \\
\quad(\mathrm{mg} \pm \mathrm{SD})\end{array}$ & $\begin{array}{l}\text { Time from Egg to Adult } \\
\text { (Days } \pm \text { SD) }\end{array}$ & $\begin{array}{c}\text { Adult Emergence } \\
\text { (Proportion } \pm \text { SD) }\end{array}$ & $\begin{array}{l}\text { Dry Adult Weight } \\
(\mathrm{mg} \pm \mathrm{SD})\end{array}$ \\
\hline \multicolumn{8}{|l|}{$\begin{array}{c}0.95 \mathrm{mg} / \text { larva } \\
\left(30^{\circ} \mathrm{C}\right)\end{array}$} \\
\hline $1: 0$ & 3 & & & & $12.33 \pm 0.57$ & $0.18 \pm 0.04$ & $0.40 \pm 0.01 \mathrm{a}$ \\
\hline $2: 1$ & 3 & $9.63 \pm 0.59 \mathrm{a}$ & $0.80 \pm 0.02 \mathrm{a}$ & $0.47 \pm 0.03 \mathrm{a}$ & $13.66 \pm 0.57$ & $0.18 \pm 0.02$ & $0.35 \pm 0.01 \mathrm{~b}$ \\
\hline $1: 1$ & 3 & $10.68 \pm 0.73 \mathrm{ab}$ & $0.78 \pm 0.10 \mathrm{a}$ & $0.35 \pm 0.03 \mathrm{~b}$ & N/A & $\begin{array}{l}.101 / \mathrm{A} \\
\mathrm{N} / \mathrm{A}\end{array}$ & N/A \\
\hline $1: 2$ & 3 & $12.08 \pm 0.02 \mathrm{~b}$ & $0.54 \pm 0.07 \mathrm{~b}$ & $0.22 \pm 0.02 \mathrm{c}$ & N/A & N/A & N/A \\
\hline $0: 1$ & 3 & $12.27 \pm 1.00 \mathrm{~b}$ & $0.24 \pm 0.04 \mathrm{c}$ & $0.25 \pm 0.03 c$ & & & \\
\hline \multicolumn{8}{|l|}{$\begin{array}{c}1.9 \mathrm{mg} / \text { larva } \\
\left(30^{\circ} \mathrm{C}\right)\end{array}$} \\
\hline 1:0 & 3 & & & & $8.76 \pm 0.35 a$ & $0.62 \pm 0.03 \mathrm{a}$ & $0.48 \pm 0.02 \mathrm{a}$ \\
\hline $2: 1$ & 3 & $5.71 \pm 0.64 \mathrm{a}$ & $0.97 \pm 0.04$ & $0.56 \pm 0.02 \mathrm{a}$ & $9.23 \pm 0.15 a$ & $0.93 \pm 0.03 \mathrm{~b}$ & $0.46 \pm 0.01 \mathrm{ab}$ \\
\hline 1:1 & 3 & $8.26 \pm 0.54 \mathrm{~b}$ & $0.93 \pm 0.07$ & $0.50 \pm 0.03 \mathrm{~b}$ & $8.68 \pm 0.29 a$ & $0.6 \pm 0.11 \mathrm{a}$ & $0.44 \pm 0.04 \mathrm{ab}$ \\
\hline $1: 2$ & 3 & $6.12 \pm 0.23 a$ & $0.95 \pm 0.08$ & $0.46 \pm 0.01 b c$ & $9.97 \pm 0.25 b$ & $1.00 \pm 0.00 \mathrm{~b}$ & $0.39 \pm 0.04 \mathrm{~b}$ \\
\hline $0: 1$ & 3 & $8.25 \pm 0.14 \mathrm{~b}$ & $0.84 \pm 0.10$ & $0.43 \pm 0.01 \mathrm{c}$ & & & \\
\hline \multicolumn{8}{|l|}{$\begin{array}{l}2.83 \mathrm{mg} / \text { larva } \\
\left(30^{\circ} \mathrm{C}\right)\end{array}$} \\
\hline 1:0 & 3 & & & & $9.19 \pm 0.20$ & $0.96 \pm 0.04$ & $0.52 \pm 0.03$ \\
\hline $2: 1$ & 3 & $7.91 \pm 0.22$ & $0.87 \pm 0.07$ & $0.69 \pm 0.01$ & $8.93 \pm 0.15$ & $0.97 \pm 0.03$ & $0.51 \pm 0.03$ \\
\hline 1:1 & 3 & $7.28 \pm 0.29$ & $0.93 \pm 0.11$ & $0.60 \pm 0.03$ & $9.29 \pm 0.61$ & $0.91 \pm 0.04$ & $0.50 \pm 0.04$ \\
\hline $1: 2$ & 3 & $7.67 \pm 0.47$ & $0.93 \pm 0.06$ & $0.61 \pm 0.05$ & $9.00 \pm 0.18$ & $0.96 \pm 0.04$ & $0.49 \pm 0.02$ \\
\hline $0: 1$ & 3 & $8.05 \pm 0.16$ & $0.93 \pm 0.07$ & $0.58 \pm 0.01$ & & & \\
\hline \multicolumn{8}{|l|}{$\begin{array}{c}1.9 \mathrm{mg} / \text { larva } \\
\left(22^{\circ} \mathrm{C}\right)\end{array}$} \\
\hline 1:0 & 3 & & & & $17.07 \pm 0.40 \mathrm{a}$ & $0.84 \pm 0.04 a$ & $0.26 \pm 0.02 \mathrm{ab}$ \\
\hline $2: 1$ & 3 & $16.01 \pm 0.55 a$ & $0.87 \pm 0.00$ & $0.60 \pm 0.07 a$ & $15.43 \pm 0.60 \mathrm{~b}$ & $0.74 \pm 0.02 \mathrm{a}$ & $0.32 \pm 0.06 \mathrm{~b}$ \\
\hline $1: 1$ & 3 & $13.81 \pm 0.52 \mathrm{~b}$ & $0.89 \pm 0.04$ & $0.52 \pm 0.03 \mathrm{~b}$ & $15.45 \pm 0.51 \mathrm{~b}$ & $0.42 \pm 0.08 \mathrm{~b}$ & $0.23 \pm 0.02 a$ \\
\hline $1: 2$ & 3 & $15.61 \pm 0.45 a$ & $0.88 \pm 0.05$ & $0.51 \pm 0.03 \mathrm{~b}$ & $14.74 \pm 0.79 \mathrm{~b}$ & $0.64 \pm 0.20 \mathrm{ab}$ & $0.30 \pm 0.03 \mathrm{ab}$ \\
\hline $0: 1$ & 3 & $15.35 \pm 0.17 a$ & $1.00 \pm 0.00$ & $0.45 \pm 0.02 \mathrm{c}$ & & & \\
\hline
\end{tabular}

Means within a column block followed by the same letter are not significantly different according to Tukey-Kramer test or Mann-Whitney $U$ test in case of no normality. Student $t$-test was used in case of 2 treatments. 
In the case of $C x$. quinquefasciatus, no significant differences were found in the dose of 2.83 $\mathrm{mg} /$ larva (Table 2). At the dose of $0.95 \mathrm{mg} /$ larva, no significant differences were found either, but in two of the tested ratios (1:1 and 1:2), no individuals of $C x$. quinquefasciatus were obtained (Table 2). In addition, the development times obtained for $C x$. quinquefasciatus at $1.9 \mathrm{mg} /$ larva showed significant differences, with a considerable reduction in the development times in those ratios where Ae. egypti individuals were at minor or equal proportions (1:0, 1:1, 2:1) (Table 2). At a food dose of $1.9 \mathrm{mg} / \mathrm{larva}$ $\left(22{ }^{\circ} \mathrm{C}\right)$, we found that at ratio 1:0 the development time was significantly the largest of all (Table 2). We also obtained only males at ratio 1:1 and a reduction in the time of development at the other ratios (data not shown), suggesting that the temperature is affecting more the survivorship of females than that of males. Moreover, we found that the development times were always shorter for Ae. aegypti than for $C x$. quinquefasciatus, although both species were affected by the availability of resources (Table 3 ).

Table 3. Comparison between biological parameters $( \pm \mathrm{SD})$ of Ae. aegypti and Cx. quinquefasciatus at different food doses under laboratory conditions.

\begin{tabular}{|c|c|c|c|c|}
\hline & $0.95 \mathrm{mg} /$ larva $\left(30^{\circ} \mathrm{C}\right)$ & $1.9 \mathrm{mg} /$ larva $\left(30^{\circ} \mathrm{C}\right)$ & $2.83 \mathrm{mg} /$ larva $\left(30^{\circ} \mathrm{C}\right)$ & $1.9 \mathrm{mg} /$ larva $\left(22^{\circ} \mathrm{C}\right)$ \\
\hline \multicolumn{5}{|l|}{$\begin{array}{l}\text { Proportion of adult } \\
\text { emergence }\end{array}$} \\
\hline Ae. aegypti & $0.59 \pm 0.24 a$ & $0.92 \pm 0.08 \mathrm{a}$ & $0.92 \pm 0.07 a$ & $0.91 \pm 0.06 \mathrm{a}$ \\
\hline Cx. quinquefasciatus & $0.18 \pm 0.03 b$ & $0.79 \pm 0.19 b$ & $0.94 \pm 0.04 \mathrm{a}$ & $0.66 \pm 0.19 b$ \\
\hline \multicolumn{5}{|l|}{ Days from egg to adult } \\
\hline Ae. aegypti & $11.17 \pm 1.27 \mathrm{a}$ & $7.10 \pm 1.29 a$ & $7.73 \pm 0.40 \mathrm{a}$ & $15.20 \pm 0.95 a$ \\
\hline Cx. quinquefasciatus & $13 \pm 0.89 b$ & $9.16 \pm 0.59 b$ & $9.10 \pm 0.33 b$ & $15.67 \pm 1.03 a$ \\
\hline \multicolumn{5}{|c|}{ Mean Dry adult weight (mg) } \\
\hline Ae. aegypti & $0.32 \pm 0.11 \mathrm{a}$ & $0.49 \pm 0.05 \mathrm{a}$ & $0.51 \pm 0.03 \mathrm{a}$ & $0.56 \pm 0.11 \mathrm{a}$ \\
\hline Cx. quinquefasciatus & $.38 \pm 0.03 a$ & $0.44 \pm 0.04 b$ & $0.62 \pm 0.05 b$ & $0.28 \pm 0.05 b$ \\
\hline
\end{tabular}

Means within a column block followed by the same letter are not significantly different according to Student $t$-test.

Regarding the adult production rate under laboratory conditions, Ae. aegypti showed no significant differences in this parameter evaluated at food dose of $1.9 \mathrm{mg} / \mathrm{larva}, 2.83 \mathrm{mg} / \mathrm{larva}$, and $1.9 \mathrm{mg} /$ larva $\left(22^{\circ} \mathrm{C}\right)$ among the different ratios tested (Table 2). At dose $0.95 \mathrm{mg} /$ larva, we found significant differences between the $C x$. quinquefasciatus/Ae. aegypti ratios, showing again a higher intraspecific vs. interspecific competition, especially at ratios 2:1 and 1:1 (Table 2).On the other hand, Cx. quinquefasciatus, at a food dose of $0.95 \mathrm{mg} /$ larva, showed no adult production at ratios 1:2, 1:1, with more or equal individuals of Ae. aegypti. At a food dose of $1.9 \mathrm{mg} / \mathrm{larva}$, we found significant differences between the ratios tested, but it seems unclear the effect of competitionon adult production at this dose. Further, at a food dose of $1.9 \mathrm{mg} /$ larva $\left(22{ }^{\circ} \mathrm{C}\right)$ there was a reduction in the adult production of $C x$. quinquefasciatus at ratios 1:2, 1:1, with more or equal individuals of Ae. aegypti. However, with a food dose of $2.83 \mathrm{mg} /$ larva no significant differences were observed in the adult production rates of $C x$. quinquefasciatus (Table 2).

Considering the dry adult weight, we observed at food doses of $0.95 \mathrm{mg} / \mathrm{larva}, 1.9 \mathrm{mg} / \mathrm{larva}$, and $1.9 \mathrm{mg} /$ larva $\left(22{ }^{\circ} \mathrm{C}\right)$ a statistical significant increase in the weight of adults of Ae. aegypti, directly related to the increase in Cx. quinquefasciatus/Ae. aegypti ratio (Table 2, Figure 2). Whereas for $C x$. quinquefasciatus, at those same food doses, an increase in weight was obtained, inversely related to the increase in the $C x$. quinquefasciatus/Ae. aegypti ratios (Figure 2). Males at $1.9 \mathrm{mg} / \mathrm{larva}$ food dose showed no weight differences at different ratios evaluated, indicating that competition at intermediate availability of resources affected further Ae. aegypti and $C x$. quinquefasciatus females. At food dose $2.83 \mathrm{mg} /$ larva no correlation or significant differences were found for both species (Table 2, Figure 2), therefore implying that in cases of food shortage or under intermediate resource conditions Ae. aegypti biomass is negatively affected by the presence of individuals of the same species rather than by the presence of $C x$. quinquefasciatus individuals. For $C x$. quinquefasciatus, we found that the biomass was negatively affected by the presence of Ae. aegypti individuals rather than by the presence of individuals of the same species. Furthermore, the mean weight of adults at different food doses showed that although individuals of $C x$. quinquefasciatus weigh more when there is an extensive availability of 
resources $(2.83 \mathrm{mg} / \mathrm{larva})$, under food scarcity there were no differences in the weight of individuals between both species, or Ae. aegypti tend to be heavier (Table 2). A comparison of all the biological parameters measured here showed that $A$ e. aegypti has a better efficiency in converting food supplied into biomass (Table 3).
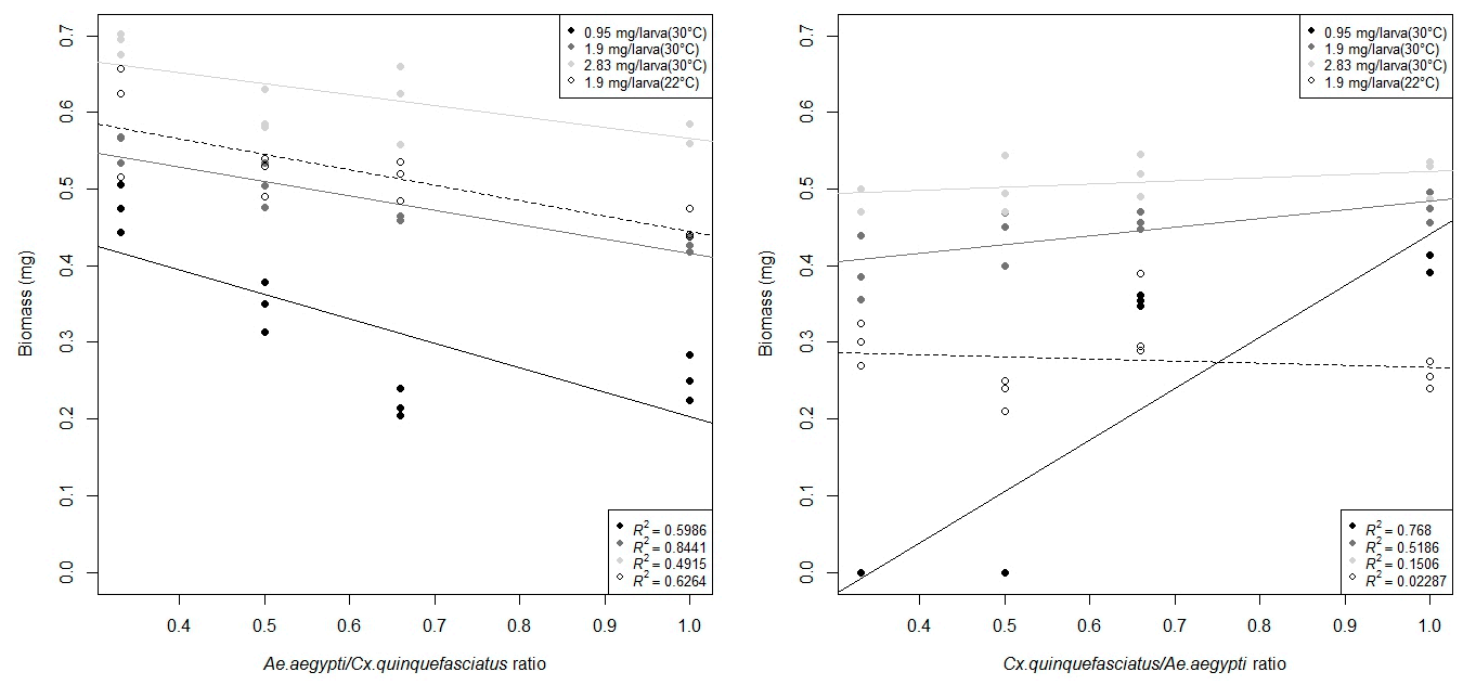

Figure 2. Relationship between adult dry biomass produced and different competition ratios between Cx. quinquefasciatus/Ae. aegypti at $22^{\circ} \mathrm{C}$ or $30^{\circ} \mathrm{C}$ and different food doses. Ae. aegypti adults (Left Panel), Cx. quinquefasciatus adults (Right Panel).

To confirm this, our measurements using the Relative Crowding Coefficient (RCC) showed that in all food doses tested the competition between $C x$. quinquefasciatus and Ae. aegypti favors the latter $\left(\mathrm{RCC}_{0.95\left(30^{\circ} \mathrm{C}\right)}: 1.085547776, \mathrm{RCC}_{1.9\left(30^{\circ} \mathrm{C}\right)}: 1.601418242, \mathrm{RCC}_{1.9\left(22^{\circ} \mathrm{C}\right)}: 1.40680578\right)$, even in those cases where there was a wide availability of resources $\left(\mathrm{RCC}_{2.83\left(30^{\circ} \mathrm{C}\right)}: 1.305095523\right)$. Apparently low competition was observed in food shortage $\left(\mathrm{RCC}_{0.95\left(30^{\circ} \mathrm{C}\right)}: 1.085547776\right)$, which is explained by the modifications to the formula that were made due to the lack of $C x$. quinquefasciatus individuals in the ratios 1:2 and 1:1 (Table 2).

\section{Discussion}

The main findings of this project showed that under simulated field conditions, food supply, temperature, space, and sun exposition were adequated for larval development and no asymmetrical competition was observed between both species, allowing their coexistence in the same breeding sites. However, under laboratory conditions and with different amount of food and temperatures, an asymmetrical competition was observed and Ae. aegypti larvae prevailed over Cx. quinquefasciatus larvae.

A previous study reported that at $30^{\circ} \mathrm{C}, \mathrm{Cx}$. quinquefasciatus showed low dry weight gain and Ae. aegypti individuals showed low rates of adult production [7]. Our field-simulated conditions showed that air temperature was $30.16 \pm 1.70{ }^{\circ} \mathrm{C}$, but contrary to expectations neither adult dry weight nor rates of adult production were affected by this temperature or the co-occurrence of the two species in the same breeding site. Likewise, biological parameters previously reported as optima at this temperature (development time, weight of $A$ e. aegypti, and survival rate of $C x$. quinquefasciatus) were also not affected, since no differences were found when the larvae were isolated from the other species.

Studies on larval development for both species [27-29] showed that competition for scarce food resources appeared to be more important than temperature influencing Ae. aegypti development in the field and in the same way more important than density influencing $C x$. quinquefasciatus development. Field simulation bioassays were performed under shade conditions, which enhanced 
the overall relative productivity of pupae [30], and with 9 liters of rainwater, which enriched larvae development due to its wide content in organic matter [27]. Also, the volume of water per larva (approximately $12 \mathrm{~mL}$ per larva) has been reported as more than enough to avoid the density-dependent effect on $C x$. quinquefasciatus [31,32] and Ae. aegypti larval development [33]. Therefore, given these adequate conditions, no competition for food or space was observed as expected.

Our experiments in field simulation conditions allow us to state that apparently under conditions of wide availability of resources, a temperature of $\pm 30^{\circ} \mathrm{C}$, and space and sun protection, no asymmetric competition was observed. However, studies are needed to evaluate competition between the two species in locations with different temperatures, space, and protection of the sun, as well as to quantify the available food in detail and to clarify how the population dynamics fluctuate in the field. In addition, a previous study [28] showed that larval mortality might be more influenced in the early larval stages by temperature and food shortages in comparison to the last larval stages; therefore, we suggest that different early larval stages should be evaluated in further studies.

Results under laboratory conditions, at $30{ }^{\circ} \mathrm{C}$ and $22{ }^{\circ} \mathrm{C}$, showed that Ae. aegypti is more successful than $C x$. quinquefasciatus in exploiting artificial microhabitats either when food supply is scarce $(0.95 \mathrm{mg} /$ larva) or at food intermediate concentration ( $1.95 \mathrm{mg} /$ larva). Thus, in conditions of food paucity, the two species were brought into competition, and Ae. aegypti succeeded over $C x$. quinquefasciatus. As a consequence, an increase in the time of development, a decrease in the overall dry weight, and metamorphosis failures of $C x$. quinquefasciatus were found (Table 2). Furthermore, RCCs measured in our experiments supported this assumption. Also, Cx. quinquefasciatus females seem to be more affected by food shortage, since males presented no differences in weights at intermediate conditions.

Change in temperature caused that development time of Ae. aegypti increase more in relation to the increase in time measured for $C x$. quinquefasciatus. However, development time of Ae. aegypti at $22{ }^{\circ} \mathrm{C}$ was lower than the time for $C x$. quinquefasciatus. As well, percentage of emergent adults and dry weight of adults of $C x$. quinquefasciatus were affected to a greater extent by the change in temperature (Table 3). We suggest that even though $C x$. quinquefasciatus survives from eclosion to adult emergence in a wide range of temperatures [7], only certain temperatures are most likely to reach development and to be successful. Moreover, despite the fact that Ae. aegypti has a narrower surviving range of temperatures, it is more efficient at converting food into biomass and having higher survival rates compared with $C x$. quinquefasciatus. However, a recent study showed that Ae. aegypti is capable of reaching pupation under constant and diurnal temperatures, ranging from $25^{\circ} \mathrm{C}$ to $35^{\circ} \mathrm{C}$, in $79 \%$ of the population, in the worst cases [34].

We suggest that laboratory results evinced an asymmetrical competition between both species in conditions of food paucity and apparently in a range of temperature of $22-30^{\circ} \mathrm{C}$. Intrinsic factors of each species may explain the asymmetry of this competition. (1) Ae. aegypti uses an active feeding mode (shredding), whereas $C x$. quinquefasciatus is considered a passive collector-filter, which presumably leads Ae. aegypti to be more efficient at resource acquisition and spend more time behaviorally active foraging or feeding [17]. (2) Ae. aegypti larvae can feed from particulate organic matter such as leaves, filaments of macroalgae, or other plant parts, and even though dead invertebrates, often of their own kind. Instead, $C x$. quinquefasciatus removes particulate organic material from suspension [17]. (3) Differences found in previous studies in regard to filtration rates: Cx. quinquefasciatus (490-590 $\mathrm{L} /$ larva/h) contrastingly to Ae. aegypti (590-690 $\mu \mathrm{L} /$ larva/h) [35]. (4) Differences found in time of the larval development for both species; Ae. aegypti larvae showed faster developing times [our results and 7, 27]. (5) Resistance to starvation in third-instar Ae. aegypti larvae, which is capable of surviving for as long as 47 days when reared with artificial food and 24 days when reared with natural food [36]. The number of days that larvae can survive without food is a function of accumulated reserves, mainly lipids [37]; therefore, Ae. aegypti, due to its exponential lipogenesis [38], is capable of surviving food privation and presumably has better efficiency converting food into biomass. 
Moreover, we found an interesting pattern in the dry weight of adults for both species according to the amount of individuals of the same species when food was limited. In the case of Ae. aegypti, we found an inverse relationship between biomass and Ae. aegypti/Cx. quinquefasciatus ratio, which would indicate a higher intraspecific vs. interspecific competition. On the other hand, for $C x$. quinquefasciatus we found a direct relationship between biomass and the $C x$. quinquefasciatus/Ae. aegypti ratio, indicating a higher interspecific vs. intraspecific competition (Figure 2). Also, the slopes of each food dose in Figure 1 demonstrated how strong the effect of intraspecific or interspecific competition was, according to the effect of food shortage. Previous studies showed similar results, indicating a positive relationship between adult size and food availability [39]. Also, studies assessing larval association between Ae. aegypti and Cx. pipiens demonstrated that Ae. aegypti was more affected by intraspecific competition than interspecific competition [40]. Density-dependent events in Ae. aegypti can be caused by mechanical interference among larvae during feeding activity. Since the encounters or collisions between individuals are greater in Ae. aegypti, higher intraspecific competition vs. interspecific competition might be expected [33]. Results of a laboratory-based study conclude that under interspecific competition, $C x$. quinquefasciatus favors Ae. aegypti because the former reduces the amount of organic matter in the media [18]. Those findings showed the same asymmetrical competition found in our experiments; however, recent evidence $[9,10,13]$ showed that Ae. aegypti occurs in containers with polluted stagnant waters rich in organic matter. Consequently, we assume intraspecific competition, and interspecific competition results might be more related to the intrinsic factors described above rather than previous findings that were related with media contamination [18].

Current evidence suggests that climate change is likely to increase the area of land with a suitable climate for Ae. aegypti, since increasing global temperatures and other associated climate changes may modify the mosquito's geographic range [41,42]. Altitudes that are currently too cool to sustain vectors will become more conducive to them. Some vector populations may expand into new geographic areas, whereas others may disappear $[43,44]$. Therefore, according to our results and taking into account that Ae. aegypti is an opportunistic species which can easily colonize empty niches [4] and has the ability to adapt to higher temperature ranges [34], there seem to be no obstacles to the spread of Ae. aegypti deriving from competition with the species $C x$. quinquefasciatus within a climate change scenario. Nevertheless, additional field studies are needed in this regard to elucidate how dynamics can vary if the environmental conditions change.

Similarly to previous studies suggestions $[33,36]$ for mosquito control, it is important to consider if total elimination of all Ae. aegypti individuals in each container is achievable. Events lightening intraspecific competition in Ae. aegypti may increase body mass and consequently produce bigger adults. Larvicidals directed to mixed populations should be very efficient in order to evade the effects of alleviation of Ae. aegypti intraspecific competition, since $C x$. quinquefasciatus is a weaker competitor. Concerning $C x$. quinquefasciatus, we suggest previous assessments of the larvicidal under larval association conditions in order to avoid biocontrol overestimation and achieve more efficient formulations.

\section{Conclusions}

This is the first study to investigate larval interactions between Ae. aegypti and Cx. quinquefasciatus. In the field-simulated conditions we found that apparently with a wide availability of resources, a temperature of $\pm 30{ }^{\circ} \mathrm{C}$, and space and sun protection, no asymmetric competition occurs. Nevertheless, we demonstrated that Ae. aegypti is a superior resource competitor and appears to be capable of competitively affecting $C x$. quinquefasciatus under conditions of limited resources and different temperatures. Although it is evidently that interspecific competition between these species is occurring and has the potential to affect vector population dynamics, there is a clear need for field investigations of both the ecological effects and epidemiological consequences of competition between these species. 
Acknowledgments: The authors are grateful to the Faculty of Sciences at Universidad de los Andes in Colombia for funding this research. Special thanks to Marlon Salgado at Secretaria de Mayor de Cundinamarca in Colombia and to Angélica María Aguirre for collecting field strains of Ae. aegypti and Cx. quinquefasciatus. Also, special thanks to Angelica María Aguirre and Maria Camila Melo for the assistance provided with the bioassays. We would like to thank Tiziana Laudato for the language corrections.

Author Contributions: Juan C. Santana-Martínez, Jorge Molina, and Jenny Dussán conceived and designed the experiments; Juan C. Santana-Martínez performed the experiments; Juan C. Santana-Martínez Jorge Molina, and Jenny Dussán analyzed the data, Juan C. Santana-Martínez and Jenny Dussán contributed reagents/materials/analysis tools; Juan C. Santana-Martínez wrote the paper.

Conflicts of Interest: The authors declare no conflict of interest.

\section{References}

1. Morrison, A.C.; Zielinski-Gutierrez, E.; Scott, T.W.; Rosenberg, R. Defining challenges and proposing solutions for control of the virus vector Aedes aegypti. PLoS Med. 2008, 5. [CrossRef] [PubMed]

2. Features Creatures: Southern House Mosquito. Available online: http://entnemdept.ufl.edu/creatures/ aquatic/southern_house_mosquito.htm (accessed on 2 October 2016).

3. Chadee, D.D.; Ward, R.A.; Novak, R.J. Natural habitats of Aedes aegypti in the caribbean-A Review. J. Am. Mosq. Control Assoc. 1998, 14, 5-11. [PubMed]

4. Powell, J.R.; Tabachnick, W.J. History of domestication and spread of Aedes aegypti-A Review. Mem. Inst. Oswaldo Cruz 2013, 108, 11-17. [CrossRef] [PubMed]

5. Molaei, G.; Andreadis, T.G.; Armstrong, P.M.; Bueno, R.; Dennett, J.A.; Real, S.V.; da Rosa, A.T. Host feeding pattern of Culex quinquefasciatus (Diptera: Culicidae) and its role in transmission of West Nile virus in Harris County, Texas. Am. J. Trop. Med. Hyg. 2007, 77, 73-81. [CrossRef] [PubMed]

6. McCall, P.J.; Eaton, G. Olfactory memory in the mosquito Culex quinquefasciatus. Med. Vet. Entomol. 2001, 15, 197-203. [CrossRef] [PubMed]

7. Rueda, L.M.; Patel, K.J.; Axtell, R.C.; Stinner, R.E. Temperature-dependent development and survival rates of Culex quinquefasciatus and Aedes aegypti (Diptera: Culicidae). J. Med. Entomol. 1990, 27, 892-898. [CrossRef] [PubMed]

8. Rozendaal, J.A. Vector Control: Methods for Use by Individuals and Communities; WHO: Geneva, Switzerland, 2007.

9. Barrera, R.; Amador, M.; Diaz, A.; Smith, J.; Muñoz-Jordan, J.L.; Rosario, Y. Unusual productivity of Aedes aegypti in septic tanks and its implications for dengue control. Med. Vet. Entomol. 2008, 22, 62-69. [CrossRef] [PubMed]

10. Burke, R.; Barrera, R.; Lewis, M.; Kluchinsky, T.; Claborn, D. Septic tanks as larval habitats for the mosquitoes Aedes aegypti and Culex quinquefasciatus in Playa-Playita, Puerto Rico. Med. Vet. Entomol. 2010, 24, 117-123. [CrossRef] [PubMed]

11. Harbison, J.E.; Metzger, M.E.; Walton, W.E.; Hu, R. Evaluation of factors for rapid development of Culex quinquefasciatus in belowground stormwater treatment devices. J. Vector Ecol. 2009, 34, 182-190. [CrossRef] [PubMed]

12. Subra, R. Biology and control of Culex pipiens quinquefasciatus Say, 1823 (Diptera, Culicidae) with special reference to Africa. Int. J. Trop. Insect Sci. 1981, 1, 319-338. [CrossRef]

13. Obando, R.G.; Gamboa, F.; Perefán, O.; Suarez, M.F.; Lerma, J.M. Experiencia de un análisis entomológico de criaderos de Aedes aegypti y Culex quinquefasciatus en Cali, Colombia. Rev. Colomb. Entomol. 2007, 33, 148-156, In Spanish.

14. Rivera, N.; Secretary of Health, Tauramena, Casanare, Colombia. Personal communication, 2017.

15. Farajollahi, A.; Fonseca, D.M.; Kramer, L.D.; Kilpatrick, A.M. "Bird biting” mosquitoes and human disease: A review of the role of Culex pipiens complex mosquitoes in epidemiology. Infect. Genet. Evol. 2011, 11, 1577-1585. [CrossRef] [PubMed]

16. Kraemer, M.U.; Sinka, M.E.; Duda, K.A.; Mylne, A.Q.; Shearer, F.M.; Barker, C.M.; Hendrickx, G. The global distribution of the arbovirus vectors Aedes aegypti and Ae. albopictus. eLife 2015, 4. [CrossRef] [PubMed]

17. Merritt, R.W.; Dadd, R.H.; Walker, E.D. Feeding behavior, natural food, and nutritional relationships of larval mosquitoes. Annu. Rev. Entomol. 1992, 37, 349-374. [CrossRef] [PubMed] 
18. Rios, A.A.; Machado-Allison, C.E.; Rabinovich, J.E.; Rodriguez, D.J. Competencia intra e interespecífica en Aedes aegypti (L.) y Culex fatigans (Wiedemann) (Diptera: Culicidae) en condiciones de laboratorio. Acta Cient. Venez. 1978, 29, 467-472. (In Spanish) [PubMed]

19. Leisnham, P.T.; LaDeau, S.L.; Juliano, S.A. Spatial and temporal habitat segregation of mosquitoes in urban Florida. PLoS ONE 2014, 9. [CrossRef] [PubMed]

20. Carrieri, M.; Bacchi, M.; Bellini, R.; Maini, S. On the competition occurring between Aedes albopictus and Culex pipiens (Diptera: Culicidae) in Italy. Environ. Entomol. 2003, 32, 1313-1321. [CrossRef]

21. R Core Team. R: A Language and Environment for Statistical Computing; R Foundation for Statistical Computing: Vienna, Austria, 2016; ISBN 3-900051-07-0. Available online: http://www.Rproject.org/ (accessed on 15 October 2016).

22. Zar, J.H. Biostatistical Analysis, 4th ed.; Prentice Hall: Upper Saddle River, NJ, USA, 1999; p. 663.

23. Harper, J.P.; Paulson, S.L. Reproductive isolation between Florida strains of Aedes aegypti and Aedes albopictus. J. Am. Mosq. Control Assoc. 1994, 10, 88-92. [PubMed]

24. Novak, M.G.; Higley, L.G.; Christianssen, C.A.; Rowley, W.A. Evaluating larval competition between Aedes albopictus and Ae. triseriatus (Diptera: Culicidae) through replacement series experiments. Environ. Entomol. 1993, 22, 311-318. [CrossRef]

25. Oberg, A.L.; Young, L.J.; Higley, L.G. A comparison of two measures of competition. J. Agric. Biol. Environ. Stat. 1996, 1, 393-403. [CrossRef]

26. Juliano, S.A. Species interactions among larval mosquitoes: Contet dependence across habitat gradients. Ann. Rev. Entomol. 2008, 54, 37-56. [CrossRef] [PubMed]

27. Tun-Lin, W.; Burkot, T.R.; Kay, B.H. Effects of temperature and larval diet on development rates and survival of the dengue vector Aedes aegypti in north Queensland, Australia. Med. Vet. Entomol. 2000, 14, 31-37. [CrossRef] [PubMed]

28. Southwood, T.R.E.; Murdie, G.; Yasuno, M.; Tonn, R.J.; Reader, P.J. Studies on the life budget of Aedes aegypti in Wat Samphaya, Bangkok, Thailand. Bull. WHO 1972, 46, 211-226. [PubMed]

29. Suleman, M. The effects of intraspecific competition for food and space on the larval development of Culex quinquefasciatus. Mosq. News 1982, 42, 347-356.

30. Vezzani, D.; Albicocco, A.P. The effect of shade on the container index and pupal productivity of the mosquitoes Aedes aegypti and Culex pipiens breeding in artificial containers. Med. Vet. Entomol. 2009, 29, 78-84. [CrossRef] [PubMed]

31. Dye, C. Competition amongst larval Aedes aegypti: The role of interference. Ecol. Entomol. 1984, 9, 355-357. [CrossRef]

32. Agnew, P.; Haussy, C.; Michalakis, Y. Effects of density and larval competition on selected life history traits of Culex pipiens quinquefasciatus (Diptera: Culicidae). J. Med. Entomol. 2000, 37, 732-735. [CrossRef] [PubMed]

33. Maciá, A. Differences in performance of Aedes aegypti larvae raised at different densities in tires and ovitraps under field conditions in Argentina. J. Vector Ecol. 2006, 31, 371-377. [CrossRef]

34. Mohammed, A.; Chadee, D.D. Effects of different temperature regimens on the development of Aedes aegypti (L.) (Diptera: Culicidae) mosquitoes. Acta Trop. 2011, 199, 38-43. [CrossRef] [PubMed]

35. Aly, C. Filtration rates of mosquito larvae in suspensions of latex microspheres and yeast cells. Entomol. Exp. Appl. 1988, 46, 55-61. [CrossRef]

36. Arrivillaga, J.; Barrera, R. Food as a limiting factor for Aedes aegypti in water-storage containers. J. Vector Ecol. 2004, 29, 11-20. [PubMed]

37. Gilpin, M.E.; McClelland, G. Systems analysis of the yellow fever mosquito Aedes aegypti. Fortschr. Zool. 1979, 25, 355-388. [PubMed]

38. Timmermann, S.E.; Briegel, H. Larval growth and biosynthesis of reserves in mosquitoes. J. Insect Physiol. 1999, 45, 461-470. [CrossRef]

39. Koella, J.C.; Offenberg, J. Food availability and parasite infection influence the correlated responses of life history traits to selection for age at pupation in the mosquito Aedes aegypti. J. Evol. Biol. 1999, 12, 760-769. [CrossRef]

40. Francia, A.; Maciá, A. Efectos de la competencia larval en los mosquitos de contenedores artificiales, Aedes aegypti y Culex pipiens (Diptera: Culicidae) en condiciones semi-controladas. Rev. Soc. Entomol. Argent. 2011, 70, 305-315, In Spanish. 
41. Khasnis, A.A.; Nettleman, M.D. Global warming and infectious disease. Arch. Med. Res. 2005, 36, $689-696$. [CrossRef] [PubMed]

42. Reiter, P. Climate change and mosquito-borne disease. Environ. Health Perspect. 2001, 109, 141-161. [CrossRef] [PubMed]

43. Shope, R. Global climate change and infectious diseases. Environ. Health Perspect. 1991, 96, 171-174. [CrossRef] [PubMed]

44. Hales, S.; De Wet, N.; Maindonald, J.; Woodward, A. Potential effect of population and climate changes on global distribution of dengue fever: An empirical model. J. Lancet 2002, 360, 830-834. [CrossRef]

(C) 2017 by the authors. Licensee MDPI, Basel, Switzerland. This article is an open access article distributed under the terms and conditions of the Creative Commons Attribution (CC BY) license (http:/ / creativecommons.org/licenses/by/4.0/). 